\title{
MODEL PEMBANGKIT DATA CURAH HUJAN: STUDI KASUS STASIUN SIMPANG ALAI KOTA PADANG
}

\author{
Nofi Yendri Sudiar \\ Jurusan Fisika Universitas Negeri Padang \\ Jl. Prof Dr. Hamka Air tawar Barat Padang. \\ Email: n_sudiar@yahoo.com
}

\begin{abstract}
The effort on constructing weather data generator to cope with the scarcity of daily rainfall data is becoming essential recently. The objective of the paper is to generate rainfall daily data using stochastic spreadsheet. This technique can generate random values derived from the Gamma distribution which is initiated by the determination of rainfall probabilities, the occurrences on certain days and followed by the generation of rainfall height. The result showed that the rainfall data generator in Padang at period 1976-2005 showed consistent patterns with the observation eventhough simulation on day $180^{\text {th }}$ the value is too high. Based on T-paired test, it showed no statistically significant different between simulation and observation $(\mathrm{P}-\mathrm{Value}=0.000$ ). Thus, the model can be employed as daily rainfall generator that can be further used to support the sustanaibility of agricultural activitiesin and food security in Padang.
\end{abstract}

Key words: the scarcity, Gamma distribution, food security

\section{PENDAHULUAN}

Kajian iklim yang dibutuhkan untuk keperluan bidang ilmu tertentu sangat membutuhkan data harian. Data harian ini akan sangat membantu membuat model dalam skala mikro. Namun tidak selamanya data harian tersebut diperoleh karena tidak semua daerah mempunyai data harian, kebanyakan data bulanan. Kalaupun ada data harian jarang yang lengkap, sering hilang atau kosong. Oleh karena itu dibutuhkankan pembangkit data iklim untuk mengatasi permasalahan tersebut.

Kota Padang adalah ibukota Propinsi Sumatera Barat yang terletak di pantai barat pulau Sumatera dan berada antara $0^{\circ} 44^{\prime} 00^{\prime \prime}$ Lintang Selatan (LS) dan $1^{0} 08^{\prime} 35^{\prime \prime}$ Lintang Selatan serta antara $100^{\circ} 05^{\prime} 05^{\prime}$ " Bujur Timur (BT) dan 100034'09" Bujur Timur. Wilayah kota
Padang memiliki topografi yang bervariasi, perpaduan daratan yang landai dan perbukitan bergelombang yang curam. Sebagian besar topografi wilayah Kota Padang memiliki tingkat kelerengan lahan rata-rata > 40\%. Ketinggian wilayah Kota Padang dari permukaan laut juga bervariasi, mulai 0 sampai $>1.000 \mathrm{mdpl}$.

Pola curah hujan kota Padang termasuk pola ekuator dimana puncak curah hujan terjadi pada bulan Maret dan Nopember (Gambar 1). Curah hujan sepanjang tahun cukup tinggi, terlihat dari harga rata-rata bulanannya > 200 $\mathrm{mm}$, ini berarti hujan dominan diakibatkan oleh penguapan air laut. Pada bulan Juli (musim kemarau) justru curah hujan cukup tinggi, hal ini menunjukkan adanya pengaruh evapotranspirasi dari hutan tropis yang ada di wilayah Padang (Sudiar, 2012). 


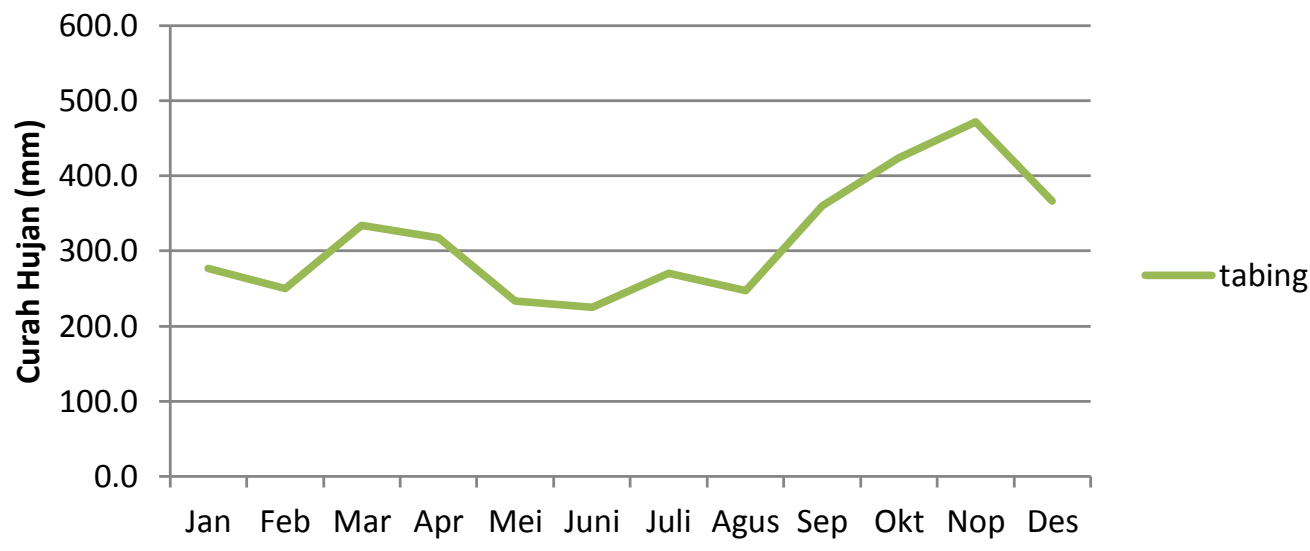

Gambar 1. Curah hujan rata-rata bulanan stasiun Tabing kota Padang periode 1980-2010.

Curah hujan yang sangat tinggi dan kondisi topografi kota Padang yang sebagian besar sangat curam memicu potensi bencana longsor dan banjir. Potensi yang ada ini jika tidak disadari akan mengancam penduduk kapan saja, karena sepanjang tahun kota Padang selalu mendapatkan curah hujan yang tinggi. Daerahdaerah yang menjadi wilayah resapan air dan kawasan hutan harus terus selalu dijaga agar tidak berubah fungsi menjadi kawasan hunian dan komersialisasi. Ini berarti keseimbangan hidrologi harus terus dipertahankan. Jika keseimbangan ini diganggu dapat dipastikan bencana longsor dan banjir hanya menunggu waktu.

Oleh karena itulah diperlukan kajian ini agar kebutuhan data yang rapat untuk pengelolaan bencana dapat dilakukan dengan lebih baik. Tujuan studi ini adalah untuk membangkitkan data curah hujan menggunakan teknik stokastik yang dapat dijalankan pada aplikasi spreadsheet di Kota Padang.

\section{METODE PENELITIAN}

Data yang dipakai adalah data curah hujan yang didapat dari Dinas Pengelolaan Sumber Daya Air (PSDA) Sumbar stasiun Simpang Alai selama periode 1976-2005 dengan koordinat $00^{\circ} 56^{\prime} 04^{\prime \prime}$ LS dan $100^{\circ} 26^{\prime} 20^{\prime \prime}$ BT.

Model pembangkit data iklim yang agak rumit penyusunannya adalah model pembangkit data hujan karena hujan merupakan unsur iklim yang sangat besar variasinya dari waktu ke waktu maupun dari satu tempat ke tempat yang lain.

Penggambaran kejadian hujan seringkali menggunakan model rantai Markov (Haan et al., 1976; Coe \& Stern,1982) dalam Boer (tanpa tahun). Diasumsikan bahwa kejadian hujan pada hari ke-i dipengaruhi oleh kejadian hujan pada hari sebelumnya (i-1) maka dikatakan bahwa kejadian hujan tersebut membentuk rantai Markov ordo 1, dan bila dipengaruhi oleh keadaan dua hari sebelumnya, maka membentuk rantai Markov ordo 2 dan seterusnya.

Dalam model digunakan rantai rantai Markov ordo satu, hari hujan disimbulkan dengan 1 dan hari tidak hujan disimbulkan dengan 0 . Peluang kejadian hujan pada hari kei jika pada hari sebelumnya terjadi atau tidak terjadi hujan disimbulkan dengan $\mathrm{P}_{\mathrm{j} 1}(\mathrm{i})$.

Ada empat tahap dalam penyusunan model kejadian hujan, yaitu (1) Menentukan nilai peluang kejadian hujan $\mathrm{P}_{01}(\mathrm{i})$ dan $\mathrm{P}_{11}(\mathrm{i})$; (2) Membuat kurva penyesuaian $\mathrm{g}_{01}(\mathrm{i})$ dan $\mathrm{g}_{11}(\mathrm{i})$ dengan deret Fourier; (3) Transformasi kembali $\mathrm{g}_{01}(\mathrm{i})$ dan $\mathrm{g}_{11}$ (i) kebentuk $\mathrm{P}_{01}(\mathrm{i})$ dan $\mathrm{P}_{11}(\mathrm{i})$; dan (4) Membangkitkan nilai kejadian hujan $\mathrm{kh}_{01}(\mathrm{i})$ dan $\mathrm{kh}_{11}(\mathrm{i})$. Bentuk umum nilai dugaan peluang kejadian hujan ialah sebagai berikut:

$$
p_{j 1}(i)=\frac{n_{j 1}(i)}{n_{j 1}(i)+n_{j k}(i)}
$$

$$
\begin{aligned}
& \text { Dimana: } \\
& \mathrm{p} \text { kejadian hujan }
\end{aligned}=\text { peluang }
$$




$$
\begin{aligned}
& \mathrm{n} \quad=\text { jumlah } \\
& \text { kejadian hujan } \\
& \mathrm{j}, 1, \mathrm{k}=\text { notasi kejadian hujan } \\
& \text { bersyarat (0 dan } 1)
\end{aligned}
$$

Persamaan regresi Fourier yang biasa digunakan dalam penyusunan persamaan penduga peluang kejadian hujan akan menghasilkan garis fitting lebih besar dari 1 atau lebih kecil dari 0. Maka untuk menghasilkan nilai peluang yang berada diantara 0 sampai 1 , persamaan garis fitting peluang kejadian hujan $\mathrm{P}_{\mathrm{jl}}$ (i) ditransformasikan ke dalam bentuk fungsi logit $\mathrm{g}_{\mathrm{j} l}(\mathrm{i})$ dengan persamaan berikut :

$$
g_{j l}(i)=\ln \frac{P_{j l}(i)}{\left(1-P_{j l}(i)\right)}
$$

\section{(2)}

Selanjutnya dilakukan kurva penyesuaian $\mathrm{g}_{\mathrm{jl}}(\mathrm{i})$ dengan persamaan garis fitting (deret Fourier) :

$$
g_{j l}(i)=a_{j l 0}+\sum_{k=1}^{m}\left[a_{j l k} \operatorname{Sin}\left(k i^{*}\right)+b_{j l k}\right.
$$

Dimana :

$$
\begin{aligned}
& \mathrm{i}^{*}=2 \pi \mathrm{i} / 365 \\
& \mathrm{i}=1,2,3, \ldots 365
\end{aligned}
$$

$\mathrm{a}_{0}, \mathrm{a}_{\mathrm{k}}, \& \mathrm{~b}_{\mathrm{k}}=$ konstanta yang dihitung

$\mathrm{m}=$ jumlah harmonik

Banyaknya harmonik (m) dapat ditentukan dengan menggunakan teknik regresi berganda, yaitu peubah bebas dimasukkan secara berurutan, mulai dari harmonik 1 , harmonik 2 dan seterusnya hingga tidak ada lagi penambahan keragaman yang diterangkan oleh peubah bebas yang dimasukkan.

Untuk keperluan simulasi, data peluang harus diubah ke dalam bentuk data kejadian hujan. Hal ini dilakukan dengan cara membangkitkan bilangan acak dari sebaran uniform U(0,1). Van Tass et al.(1990) dalam Boer (tanpa tahun). Bila nilai acak dari sebaran uniform lebih kecil dari nilai peluang, maka berarti hujan, sebaliknya bila nilai acak lebih besar dari sebaran uniform berarti tidak terjadi hujan. Bila hasilnya menunjukkan terjadi hujan, maka tahap selanjutnya adalah membangkitkan data tinggi hujan dengan menggunakan sebaran teoritis.

Sebaran teoritis umum yang sering digunakan untuk mendekati sebaran data hujan adalah sebaran gamma karena sebaran gamma dapat menggambarkan keragaman tinggi hujan sebagaimana dijelaskan oleh Ison et al. (1971); Stern dan Coe (1984); Waggoner (1989); Wilks (1990) dalam Boer (tanpa tahun). Adapun model kepekatannya adalah :

$$
f(x, \alpha, \beta)=\frac{\left[\frac{x}{\beta}\right]^{\alpha-1} \exp \left[-\frac{x}{\beta}\right]}{\beta \Gamma(\alpha)}
$$

dimana $\alpha$ adalah parameter bentuk, $\beta$ adalah parameter skala dan $\Gamma$ adalah fungsi Gamma. Banyak metode yang dapat digunakan untuk menduga parameter sebaran gamma tersebut, beberapa diantaranya adalah metode moment dan metode kemungkinan maksimum yaitu: metode Thom dan metode Greenwood dan Durand. Namun dalam studi ini parameter sebaran gamma diduga dengan menggunakan program aplikasi stokastik spreadsheet (Crystal $\underset{\operatorname{Cos}\left(K i^{*}\right)}{\operatorname{Bath}}$

kurang tersedia. tersedia umumnya dalam bentuk data bulanan. Untuk mendapatkan data harian dari data bulanan, Epstein sudah mengembangkan metode untuk membangkit data harian dari data bulanan yaitu dengan menggunakan regresi Fourier. Persamaannya dituliskan sebagai berikut (Epstein, 1991):

$$
P(t)=a_{0}+\sum\left[a_{k} \sin \left(k t^{\prime}\right)+b_{k} \cos \left(k t^{\prime}\right)\right]
$$

dengan $\mathrm{t}^{\prime}=2 \pi \mathrm{t} / 12$, dan $\mathrm{t}$ adalah indeks bulan. Pada persamaan (5) ini kita menganggap bahwa banyaknya hari untuk tiap bulan adalah sama walaupun pada kenyataanya tidak sama. Oleh karena itu untuk menyesuaiannya, maka nilai $t$ persamaan di atas diubah sebagai hari ke-m untuk bulan ke- $\mathrm{T}$ dan nilai $\mathrm{t}=(\mathrm{T}-0.5)+(\mathrm{m}-$ $0.5) / \mathrm{D}$, dimana $\mathrm{D}$ adalah banyaknya hari pada bulan T. Pada tulisan ini khusus akan dibahas tentang bagaimana membangkit data suhu ratarata harian dari data suhu rata-rata bulanan. Meskipun sebenarnya dalam membangkit data iklim selain curah hujan, peubah hujan seringkali diikutsertakan (McCaskill, 1990) karena pada umumnya unsur iklim yang lain dipengaruhi oleh kondisi hujan. Misalnya pada kondisi hujan umumnya suhu udara relatif rendah, sebaliknya pada hari-hari tidak hujan. 


\section{HASIL DAN PEMBAHASAN}

Curah hujan rata-rata bulanan pada stasiun Simpang Alai adalah $325 \mathrm{~mm}$ dengan curah hujan minimum terjadi pada bulan Februari sebesar $210 \mathrm{~mm}$ dan maksimum pada bulan November sebesar $468 \mathrm{~mm}$. Posisi stasiun ini yang berada pada kelerengan lahan 3-15\% atau topografi yang bergelombang, namun tidak di lereng perbukitan sehingga jenis hujan yang dominan adalah hujan konvektif.

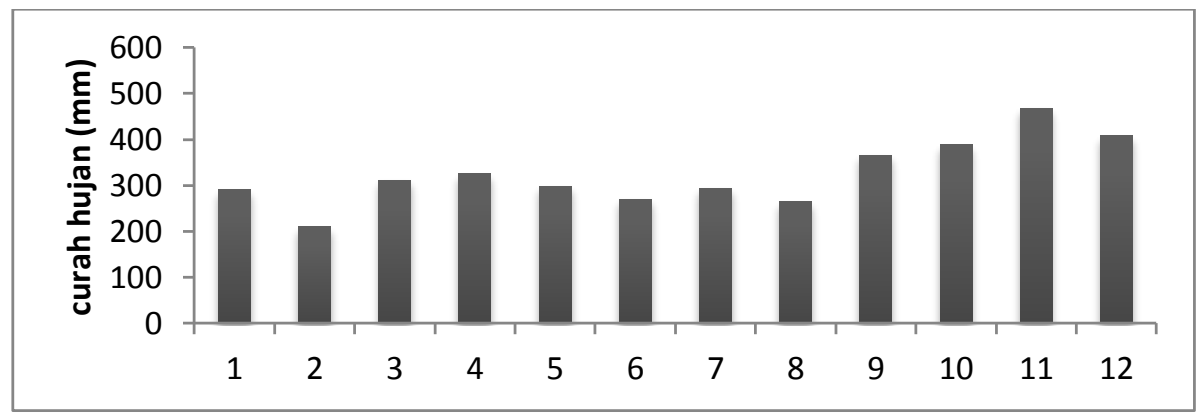

Gambar 2. Curah hujan rata-rata bulanan stasiun Simpang Alai periode 1976-2005.

Analisis regresi Fourier terhadap data hujan harian di stasiun Simpang Alai kota Padang terlihat bahwa kurva fitting $\mathrm{g}_{01}$ dan $\mathrm{g}_{11}$ (gambar 3 dan 4) menunjukkan peluang kejadian hujan mengikuti pola musiman sebagaimana ditunjukkan pada gambar 1 . Kurva fitting $\mathrm{g}_{01}$ menyatakan kejadian hujan pada hari ke-i dipengaruhi oleh kejadian satu hari sebelumnya, dimana satu hari sebelumnya tidak terjadi hujan sedangkan $g_{11}$ menyatakan kejadian hujan pada hari ke-i dipengaruhi oleh kejadian satu hari sebelumnya, dimana satu hari sebelumnya terjadi hujan.

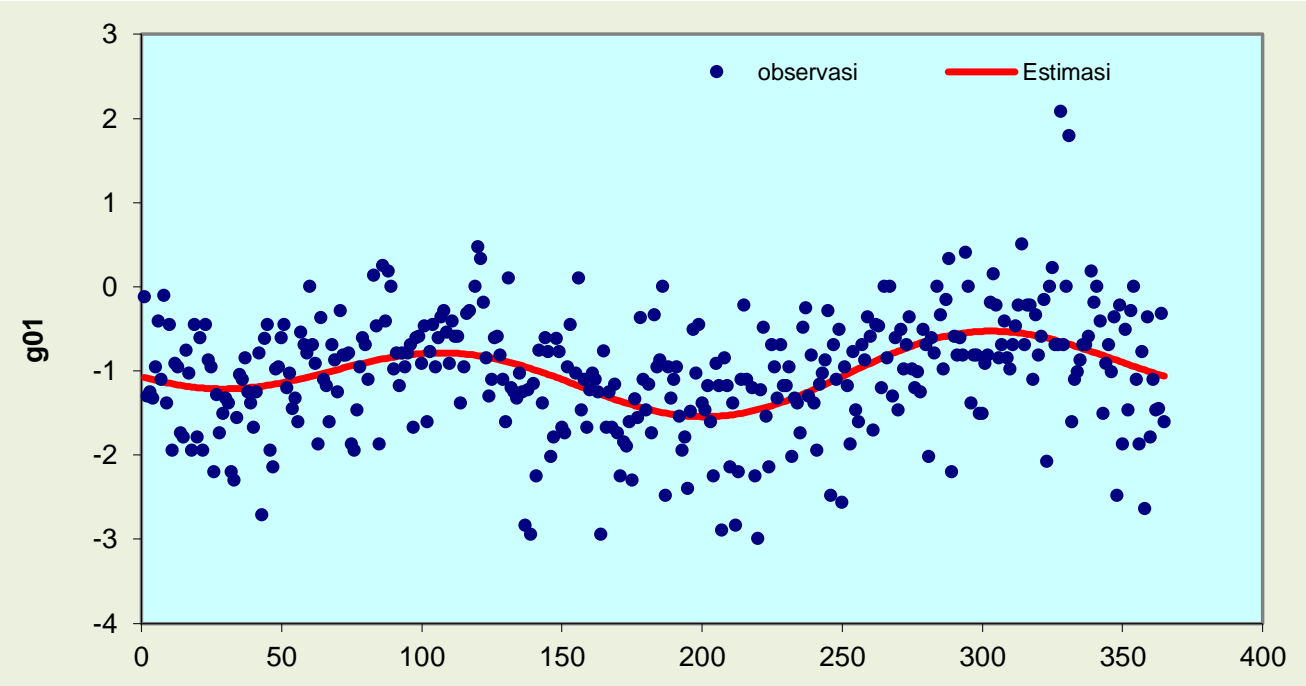

Gambar 3. Kurva fitting $\mathrm{g}_{01}$ data hujan harian stasiun Simpang Alai kota Padang 


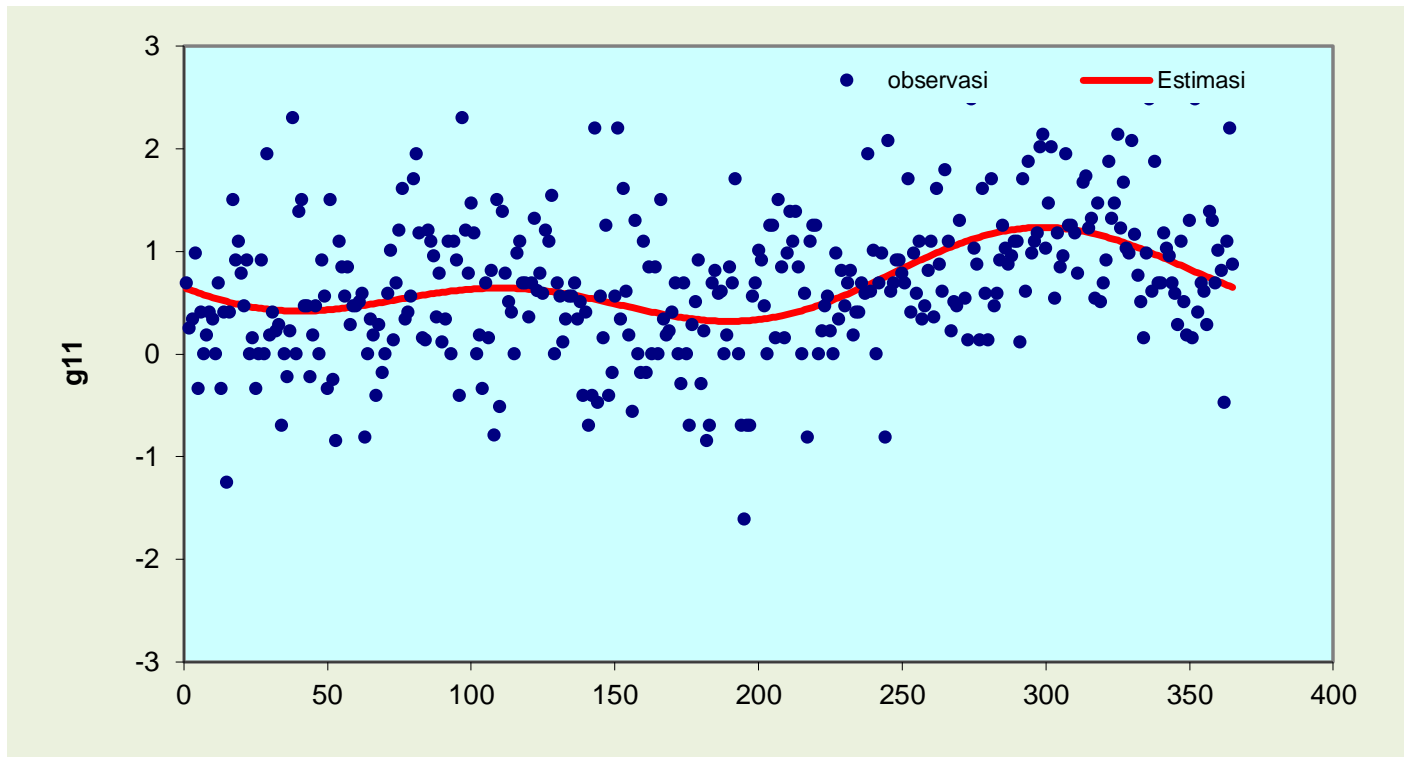

Gambar 4. Kurva fitting $\mathrm{g}_{11}$ data hujan harian stasiun Simpang Alai kota Padang

Untuk membangkitkan data hujan digunakan sebaran teoritis yaitu sebaran Gamma. Berdasarkan analisis deret Fourier diperoleh koefisien persamaan pembangkit data hujan di kota Padang seperti ditunjukkan pada tabel 1 .
Pendugaan peluang kejadian hujan di kota Padang menunjukkan pola bulan kering dan basah maka analisis pendugaan parameter sebaran Gamma dilakukan berdasarkan musiman tersebut. Parameter $\alpha$ dan $\beta$ pada bulan basah dan bulan kering seperti ditunjukkan pada tabel 2.

Tabel 1. Koefisien persamaan pembangkit data hujan untuk data curah hujan di kota Padang.

\begin{tabular}{cccccc}
\hline koefisien & $\mathrm{a}_{0}$ & $\mathrm{~b}_{1}$ & $\mathrm{c}_{1}$ & $\mathrm{~b}_{2}$ & $\mathrm{c}_{2}$ \\
\hline $\mathrm{g}_{01}$ & $-1,02000$ & $-0,05560$ & 0,20300 & $-0,25200$ & $-0,24800$ \\
$\mathrm{~g}_{11}$ & 0,67400 & $-0,25300$ & 0,16100 & $-0,18600$ & $-0,18600$ \\
\hline
\end{tabular}

Tabel 2. Parameter sebaran Gamma untuk data curah hujan di kota Padang.

\begin{tabular}{ccccc}
\hline \multirow{2}{*}{ Parameter } & \multicolumn{2}{c}{ Bulan Kering } & \multicolumn{2}{c}{ Bulan Basah } \\
\cline { 2 - 5 } & Kondisi 01 & Kondisi 11 & Kondisi 01 & Kondisi 11 \\
\hline$\alpha$ & 0,36842 & 0,6698 & 0,3826 & 0,7101 \\
$\beta$ & 57,62 & 37,77 & 61,02 & 34,80 \\
\hline
\end{tabular}

Nilai parameter Gamma yang dikelompokkan berdasarkan bulan basah dan kering diharapkan dapat menggambarkan keragaman tinggi hujan di kota Padang yang secara temporal dapat digunakan untuk menyusun model pembangkit data hujan melalui simulasi.
Perangkat lunak yang digunakan untuk pembangkit data hujan adalah Crystal Ball (CB). CB adalah aplikasi spreadsheet yang menggunakan teknik stokastik sehingga dapat membangkitkan angka-angka acak yang diberikan dari sebaran yang ditetapkan dalam sel-sel tertentu (sel asumsi) dan perhitungan formula dilakukan pada sel lain (sel forecast). 
Proses ini dapat membuat sejumlah angka-angka yang berurutan untuk menaksir jalannya nilainilai dalam sel forecast terhadap sel-sel asumsi yang diberikan. Dalam membuat program, sel asumsi harus mengandung nilai-nilai numerik bukan berupa formula atau teks. Sementara itu, sel-sel forecast harus mengandung formula yang berhubungan dengan satu atau lebih sel-sel asumsi. CB tidak dapat digunakan untuk membuat sel-sel formula, program harus dibuat dalam paket spreadsheet lain seperti Microsoft Excel. Model pembangkit data hujan disusun berdasarkan model kejadian hujan dan model tinggi hujan. Pada model kejadian hujan terdapat beberapa tahapan dalam penyusunannya yaitu:

a. Menentukan peluang kejadian hujan.

Peluang kejadian hujan $\mathrm{p}_{\mathrm{j} 1}(\mathrm{i})$ disusun berdasarkan data hujan harian sebanyak $\mathrm{n}$ tahun dengan menggunakan persamaan matematik dan ditransformasikan dalam bentuk $\mathrm{g}_{\mathrm{j} 1}(\mathrm{i})$. Hasil analisis regresi Fourier berupa nilai koefisien persamaan kurva fitting $\mathrm{g}_{01}$ dan $\mathrm{g}_{11}$ dimana nilainya sama seperti tabel 1 . Keduanya akan menjadi sel input.

b. Mentransformasikan $\mathrm{g}_{01}$ dan $\mathrm{g}_{11}$ ke dalam bentuk $\mathrm{p}_{01}$ dan $\mathrm{p}_{11}$.

Nilai $g_{j 1}$ (i) yang diperoleh dari deret Fourier di atas harus ditransformasikan kembali ke dalam bentuk nilai $p_{j 1}(i)$ untuk membangkitkan data kejadian hujannya. Persamaan peluang bersyarat kejadian hujan $\left(\mathrm{p}_{01}\right.$ dan $\mathrm{p}_{11}$ ). Keduanya merupakan sel formula.

c. Menentukan kejadian pada hari ke (i).

Untuk keperluan simulasi, nilai peluang harus diubah ke dalam bentuk data kejadian hujan (kh01 dan kh11) yaitu dengan membandingkan nilai peluang tersebut dengan bilangan acak yang dibangkitkan dari sebaran Uniform (0,1). Sebaran Uniform $(0,1)$ ditempatkan sebagai sel asumsi. Kejadian hujan untuk kondisi 01 (kh01) ditempatkan pada sebagai sel formula, sedangkan kejadian hujan untuk kondisi 11 (kh11) sebagai sel formula.

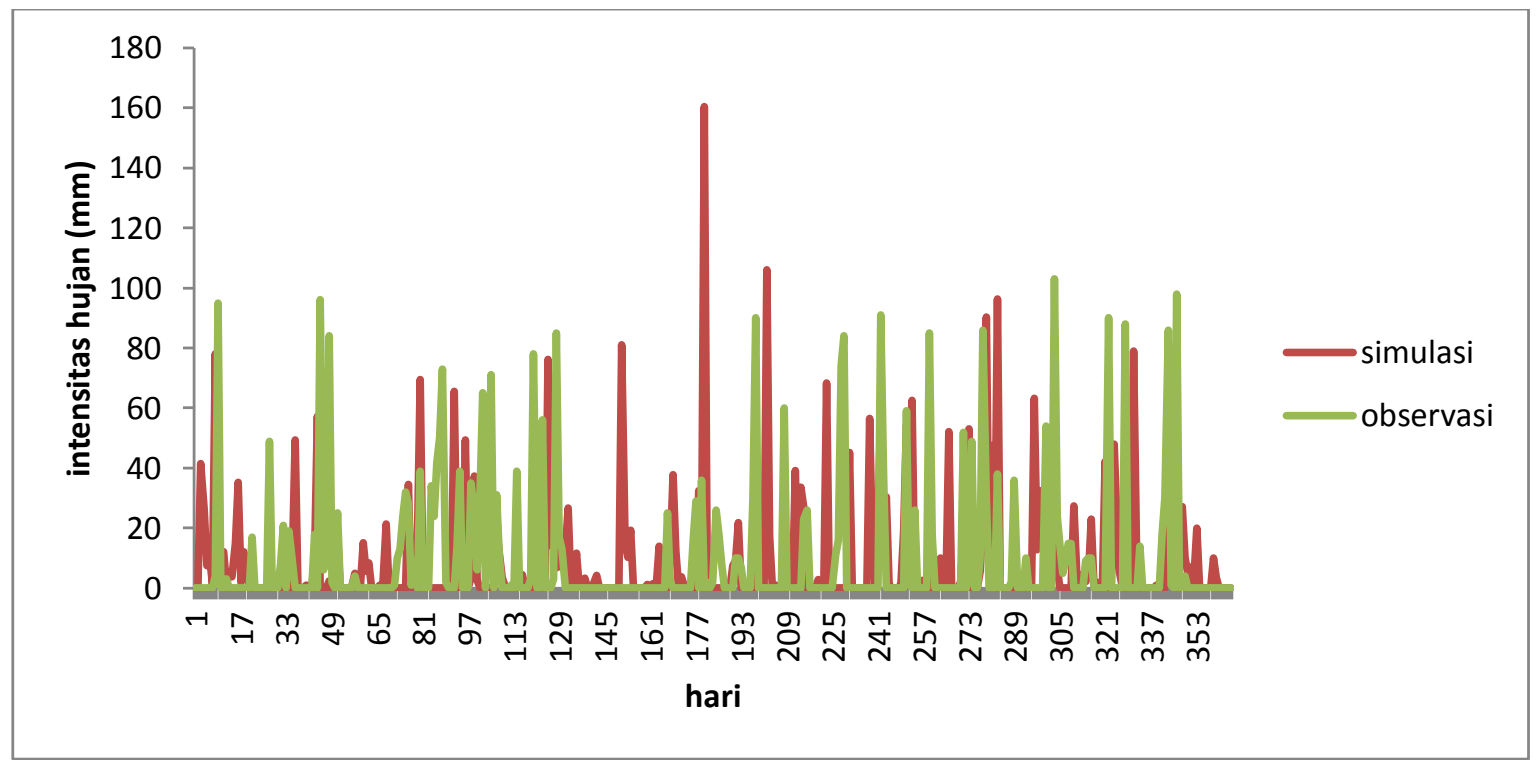

Gambar 5. Tinggi hujan simulasi dan observasi stasiun Simpang Alai kota Padang

Nilai tinggi hujan yang diperoleh dengan simulasi dapat dilihat pada gambar 5 . Hasil simulasi secara umum mengikuti pola tingi hujan observasi, meskipun ada satu simulasi pada hari ke 160 nilainya terlalu tinggi.

\section{Membangkitkan data harian dari data bulanan}

Regresi Fourier yang diperoleh dengan membangkitkan data bulanan menjadi harian sebagai berikut: 


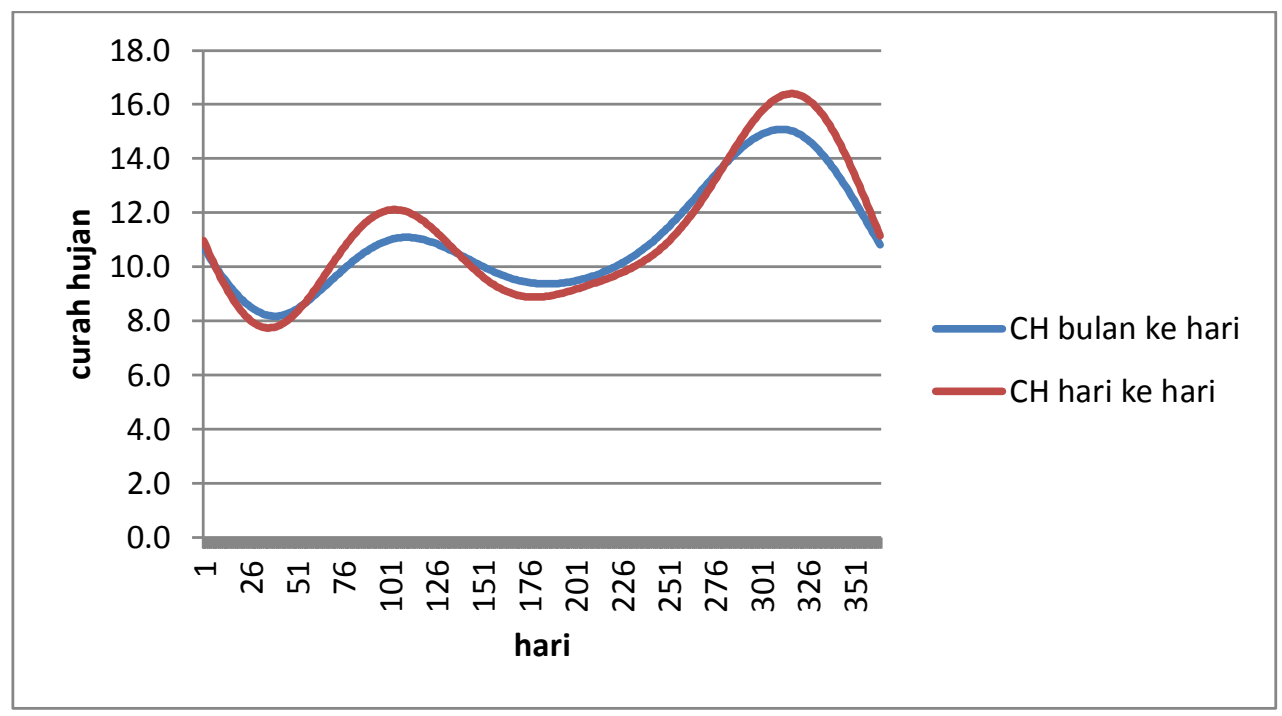

Gambar 7. Perbandingan curah hujan simulasi yang dibangkitkan dari data harian dan bulanan stasiun Simpang Alai

Namun demikian, kadang-kadang data hasil bangkitan akan berbeda nyata dengan data pengukura lapangan. Hal ini seperti yang dikemukakan oleh Jones \& Throton (1993).

Dari uji pembangkit data yang dilakukan mereka berdasarkan rantai markov orde tiga pada beberapa tempat di Amerika dan Afrika didapatkan bahwa terdapat beberapa perbedaan nyata antara hasil bangkitan dengan data pengukuran. Namun demikian, Jones dan Throton (1993) tetap berpendapat bahwa pembangkit data hujan walau bagaimana pun dapat digunakan untuk banyak aplikasi seperti aplikasi pertanian untuk menduga hasil panen.

Untuk keperluan kajian resiko iklim seperti mengisi data yang kosong, bangkitan data harian yang berasal data bulanan untuk curah hujan stasiun Simpang Alai dapat dipakai. Kebutuhan data untuk menganalisis berbagai kajian resiko iklim di berbagai bidang saat ini sangat mendesak. Dengan membangkitkan data harian dari bulanan dapat menjawab keterbatasan data harian yang ada.

Dalam kajian bahaya, kerentanan, risiko dan adaptasi perubahan iklim pada sektor pertanian menggunakan pembangkit data baik itu dari data harian ke harian maupun dari data bulanan ke harian sangat membantu dalam analisis pemicu (stimuli) kejadian bencana (hazard) seperti : (1) Peningkatan suhu udara rata-rata; (2) Perubahan pola hujan, baik curah hujan maupun periode kejadiannya; dan (3)Kejadian cuaca ekstrim berupa El-Nino dan La-Nina. Stimuli klimatis tersebut akan berdampak terhadap proses fisiologis tanaman pangan yang pada akhirnya berdampak pula terhadap produksi tanaman pangan baik langsung maupun tidak langsung.

\section{KESIMPULAN}

Keterbatasan data cuaca harian (curah hujan dan suhu udara) untuk pengelolaan bencana dapat diatasi dengan teknik pembangkitan data menggunakan spreadsheet. Teknik ini dapat membangkitkan nilai acak yang diperoleh dari sebaran Gamma. Teknik ini diawali dengan penentuan peluang kejadian hujan, penentuan kejadian hujan pada hari tertentu kemudian pembangkitan model tinggi hujan menggunakan sebaran Gamma.

Hasil simulasi secara umum mengikuti pola tingi hujan observasi, meskipun ada satu simulasi pada hari ke 160 nilainya terlalu tinggi. Hasil analisa menunjukkan bahwa secara statistika hasil bangkitan data dari dua sumber data curah hujan harian dan rata-rata bulan stasiun Simpang Alai Kota Padang tahun 19762005 ternyata tidak berbeda nyata dengan PValue $=0,000$. Artinya kedua sumber data tersebut dapat digunakan untuk membangkitkan data. Namun demikian, tentunya studi ini masih memiliki banyak kekurangan. Oleh karena itu 
diperlukan studi lebih lanjut untuk meminimalisir kesalahan yang mungkin dilakukan ketika menyusun model peluang kejadian hujan pada studi ini.

\section{DAFTAR KEPUSTAKAAN}

Boer, R. tanpa tahun. Model Pembangkit Data Iklim. Kapita Selekta Agroklimatologi. Dirjen Dikti. Dikbud. Hal: 269-290.

Epstein, E.S. 1991. on obtaining daily climatological values from monthly means. J Climate 4:365-368.
Jones, P.G. and P. K. Thornton. 1993. A rainfall generator for agricultural applications in the tropics. Agricultural and Forest Meteorology. Vol: 63, Issues 1-2.

McCaskil, M.R. 1990. An efficient method for generation of full climatological records from daily rainfall. Australian Journal of Agricultural Research 41:395 - 602.

Sudiar, Nofi Yendri., 2012: Studi Pengaruh Osilasi Madden Julian Terhadap Curah Hujan di Kota Padang. Tesis Program Studi Sains Atmosfer. ITB. Bandung 